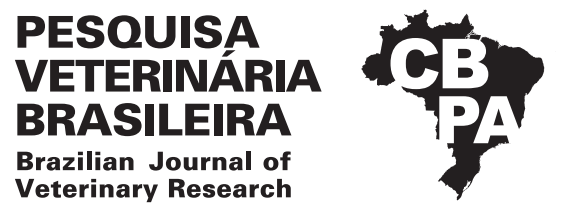

Pesq. Vet. Bras. 39(12):954-960, December 2019 DOI: 10.1590/1678-5150-PVB-5940

Original Article

ISSN 0100-736X (Print) Livestock Diseases

ISSN 1678-5150 (Online)

\title{
Antimicrobial activity of propolis extract fractions against Staphylococcus spp. isolated from goat mastitis ${ }^{1}$
}

\author{
Heidy C. Dos Santos², Dielson S. Vieira ${ }^{3}$, Sandra M. Yamamoto ${ }^{2 *}$ (D), \\ Mateus M. Costa ${ }^{2}$, Maria C.A. Sá ${ }^{2}$,Eva M.S. Silva ${ }^{2}$ and Tania M.S. Silva ${ }^{4}$
}

\begin{abstract}
Dos Santos H.C., Vieira D.S., Yamamoto S.M., Costa M.M., Sá M.C.A., Silva E.M.S. \& Silva T.M.S. 2019. Antimicrobial activity of propolis extract fractions against Staphylococcus spp. isolated from goat mastitis. Pesquisa Veterinária Brasileira 39(12):954-960. Universidade Federal do Vale do São Francisco, Rodovia BR-407, Lote 543, Projeto de Irrigação Nilo Coelho s/n, Petrolina, PE 56300-000, Brazil. E-mail: sandramariy@gmail.com

The indiscriminate use of antibiotics in the treatment of caprine mastitis causes the appearance of resistant microorganisms, besides leaving residues in milk, putting at risk to human health. In this way, propolis is an alternative in the treatment of diseases because it has antimicrobial activity, mainly because of the presence of flavonoids in its composition. The aim of this study was to evaluate the antimicrobial potential of propolis to Staphylococcus spp. Isolated from cases of goat mastitis and qualify the crude ethanoic extract by high performance liquid chromatography (HPLC). In this study, the minimum bactericidal concentration values of propolis extracts in ethanol, ethyl acetate and hexane showed that the best concentrations capable of promoting the highest mortality of the isolates of Staphylococcus spp. from mastitis in goats, were 6250,3125 and $1562.5 \mu \mathrm{g} / \mathrm{mL}$, respectively. By the microplate adherence test, it was found that $20.78 \%$ isolates were not able to form biofilm, $14.70 \%$ were classified as moderate and $64.70 \%$ were weak and none as a strong biofilm producer. Propolis in its different diluents was able to affect the formation of biofilm and showed a pronounced marked antimicrobial activity against Staphylococcus spp. strains and may be indicated for use in in vivo studies.
\end{abstract}

INDEX TERMS: Antimicrobial activity, propolis extract, Staphylococcus spp., isolated, goat mastitis, caprine, mastitis, solvents.

RESUMO.- [Atividade antimicrobiana de frações do extrato de própolis frente à Staphylococcus spp. isolados de mastite caprina.] 0 uso indiscriminado de antibióticos no tratamento de mastite caprina leva ao desenvolvimento de micro-organismos resistentes que poderão estar presentes em alimentos, colocando em risco a saúde humana. Dessa forma, a própolis surge como uma alternativa para o tratamento de doenças por possuir uma ação antimicrobiana, principalmente

\footnotetext{
${ }^{1}$ Received on June 29, 2019.

Accepted for publication on August 6, 2019.

${ }^{2}$ Graduate Program in Animal Science, Universidade Federal do Vale do São Francisco (Univasf), Rodovia BR-407, Lote 543, Projeto de Irrigação Nilo Coelho s/n, Petrolina, PE 56300-000, Brazil. *Corresponding author: sandramariy@gmail.com

${ }^{3}$ Universidade Estadual Paulista “Júlio de Mesquita Filho" (Unesp), Faculdade de Medicina Veterinária de Araçatuba, Rua Clóvis Pestana 793, Ipanema, Araçatuba, SP 16050-680, Brazil.

${ }^{4}$ Universidade Federal Rural de Pernambuco, Rua Dom Manoel de Medeiros s/n, Dois Irmãos, Recife, PE, 52171-900, Brazil.
}

pela presença de flavonoides em sua composição. 0 objetivo desse estudo foi avaliar o potencial antimicrobiano da própolis frente à Staphylococcus spp. isolados de casos de mastite caprina e qualificar o extrato etanoico bruto por cromatografia líquida de alta eficiência (CLAE-DAD). Neste estudo, os valores de concentração bactericida mínima (CBM) dos extratos de própolis em álcool etílico, acetato de etila e hexano nos isolados foram de 6250, 3125 e $1562,5 \mu \mathrm{g} / \mathrm{mL}$, respectivamente. Pelo teste de aderência à microplacas, observou-se que $20,78 \%$ dos microorganismos, não foram capazes de formar biofilme, $14,70 \%$ foram classificados como moderados, $64,70 \%$ em fracos e nenhum como forte produtor de biofilme. A própolis em seus diferentes diluentes foi capaz de afetar a formação de biofilme e apresentou significativa atividade antimicrobiana frente a cepas de Staphylococcus spp., podendo ser indicada para utilização em estudos "in vivo".

TERMOS DE INDEXAÇÃO: Atividade antimicrobiana, extrato de própolis, Staphylococcus spp., isolados, mastite caprina, cabra, própolis, solventes, caprinos. 


\section{INTRODUCTION}

Mastitis, mainly in the subclinical form, lead to damages in milk production, which directly affects milk quality and reduces the industrial yield of dairy products. There is a wide range of microorganisms that can cause mastitis, and the most common pathogens found are Staphylococcus spp. (Sampimon et al. 2010, Sá et al. 2011, Leitner et al. 2012, Peixoto et al. 2015, Acosta et al. 2016).

Defense mechanisms of these microorganisms include the production of biofilm or slime, an extracellular matrix of polysaccharides which allows the interaction between microorganisms, making difficult the action of allopathic products (Clutterbuck et al. 2007, López et al. 2010). Biofilm formation thus contributes to the resistance to the products used in routine mastitis treatment. Therefore, the search for new therapeutic alternatives is extremely important. Beekeeping products have gained space in the therapy of various diseases (Pereira et al. 2002), such as propolis, that plays a fundamental role in combating resistant microorganisms. This ability may be related to its chemical composition (Dias et al. 2012, Silva et al. 2012), as well as lower toxicity rates associated to synthetic antimicrobials (Marcucci 1995).

Propolis may have considerable concentrations of phenolic compounds, such as flavonoids and aromatic acids, as well as different types of terpenoids, justifying several beneficial potentials like antimicrobial, antioxidant, anti-inflammatory and antitumor activities (Bankova et al. 2000, Sforcin \& Bankova 2011, Valente et al. 2011). Some authors argue that the products present in propolis may change according to the season and the raw material obtained by bees (Bankova 2005, Popova et al. 2011). As an alternative product, some studies have compared the best solvent for its use and diversified applications. In this case, some of them indicated solvents are water, ethanol, combinations of two and products such as ethyl acetate and hexane (Miyataka et al. 1998, Vargas et al. 2004, Mello et al. 2010).

In this context, this study aimed to evaluate the antimicrobial effects of propolis in different solvents and fractions against Staphylococcus spp., from cases of mastitis in goats and qualify the crude ethanolic extract.

\section{MATERIALS AND METHODS}

Experiment location. The experiment was conducted at the Laboratory of Animal Microbiology and Immunology of the "Universidade Federal do Vale do São Francisco" (Univasf). Crude propolis was obtained from apiaries in the municipality of Casa Nova, state of Bahia. Subsequently, and sent to the Laboratory of Phytochemical Bioprospection of the "Universidade Federal Rural de Pernambuco" (UFRPE) for phytochemical analysis.

Phytochemical analysis of propolis extract. The propolis extract was subjected to a preliminary phytochemical analysis, aiming at the characterization of the main secondary metabolites. To analyze the potential of different fractions of propolis extract, $79.4 \mathrm{~g}$ propolis was mixed with ethanol in a beaker for extraction in an ultrasonic bath. Then, the propolis extracts in ethanol extract (EtOH) was obtained, stock solution from which the partitions were made to obtain ethyl acetate (AcOEt) and hexane extracts from propolis, as shown in Figure 1.

Thus, the EtOH extract (41.7g) was suspended in $\mathrm{MeOH}: \mathrm{H}_{2} \mathrm{O}$ (1:1) and extracted with hexane and AcOEt. After separation,

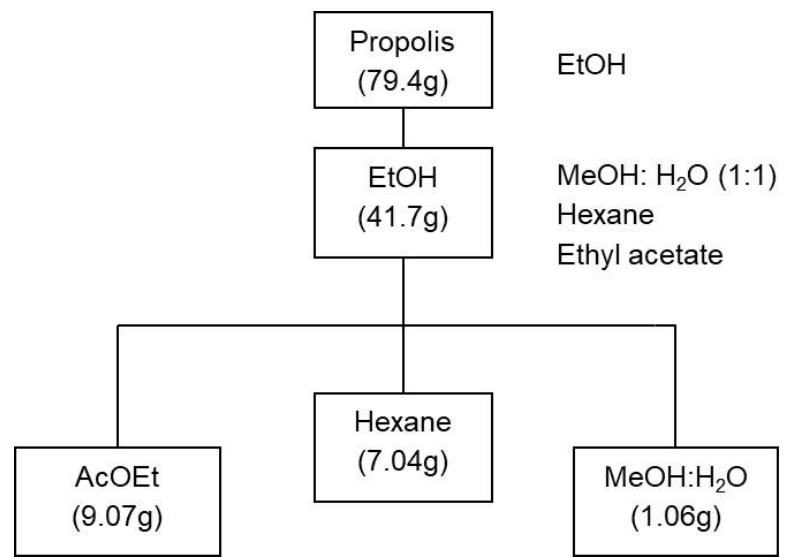

Fig.1. Extraction of propolis and propolis extracts in ethanol, ethyl acetate and hexane.

9.07g of the AcOEt fraction and 7.04g of the hexane fraction were obtained. The EtOH extract and the fractions were subjected to the total phenolic content tests (Folin-Ciocalteu), conducted in triplicates. The results were expressed as gallic acid equivalents, calculated by means of a curve constructed with concentrations ranging from 5 to $200 \mu \mathrm{g} / \mathrm{mL}$. The fractions were analyzed in high performance liquid chromatography (HPLC) and identification of the constituents of the samples was performed by comparison with previously isolated flavonoid standards of beekeeping/meliponic products.

Bacterial samples. Isolates of Staphylococcus spp. $(n=34)$ obtained from cases of subclinical mastitis in goats were used in this study, which were present in the bacterial library of the Laboratory of Animal Microbiology and Immunology. These isolates were initially identified as belonging to the genus Staphylococcus, based on the biochemical and staining characteristics (Jacques et al. 2010) and two reference strains were used, ATCC 25923 (S. aureus) and ATCC 12228 (S. apidermidis).

Preparation of stock solution. The determination of the Minimum Bactericidal Concentration (MBC) was performed based on document M07-A9 (CLSI 2012). We weighed 0.25g of the extract diluted in ethanol, ethyl acetate and hexane, which were suspended in $10 \mathrm{~mL}$ of the same solvents to obtain a stock solution at a concentration of $25,000 \mu \mathrm{g} / \mathrm{mL}$.

Preparation of inoculum. To prepare the bacterial inoculum, the $0.5 \mathrm{McF}$ arland scale equivalent was turbid in $5 \mathrm{~mL}$ of saline, then $0.1 \mathrm{~mL}$ was withdrawn and added in $9.9 \mathrm{~mL}$ of Mueller Hinton broth $(\mathrm{MH})$, which was then final suspension of use in the microdilution test.

Broth microdilution assay. 96 -well plates were used and $200 \mu \mathrm{L}$ of $\mathrm{MH}$ and $200 \mu \mathrm{L}$ of the extract were added to each well by serial dilution, starting from the stock solution up to eighth dilution and discarding the final portion. After this dilution process, $10 \mu \mathrm{L}$ of the bacterial suspension microplates were added to the wells.

The material was incubated at $37^{\circ} \mathrm{C}$ for $24 \mathrm{~h}$ under aerobic conditions. From all wells, an aliquot was taken, seeded on the surface of $\mathrm{MH}$ agar and again brought to the oven at $37^{\circ} \mathrm{C}$ for 24 hours. The MBC was defined as the lowest concentration of ethanolic extract capable of causing the death of the inoculum. As a positive control, we used the strain S. aureus ATCC 25923 due to its considered pathogenicity.

A control of the broth was carried out to evaluate if contamination and extractors occurred, in order to assess whether the effect demonstrated was related to the product or propolis. All assays were performed in triplicate. 
Assay for measurement of biofilm. The quantification of biofilm formation of the isolates was performed by means of the microplate adhesion test, with adaptations (Merino et al. 2009).

The isolated colonies were inoculated in $3 \mathrm{~mL}$ of TBS (tryptic soy broth) with glucose $(0.25 \%)$ and incubated at $37^{\circ} \mathrm{C}$ for $24 \mathrm{~h}$, to prepare the inoculum to be used in vitro. From each sample, $200 \mu \mathrm{L}$ were withdrawn where they were inoculated into 96 well plates and again incubated at $37^{\circ} \mathrm{C}$ for $24 \mathrm{~h}$. After $24 \mathrm{~h}$, three washes were performed with $200 \mu \mathrm{L}$ of distilled water. The wells were then stained with $100 \mu \mathrm{L}$ of gentian violet crystal $(0.25 \%)$ for 3 minutes and again washed with distilled water. To dissolve the dye, $200 \mu \mathrm{L}$ of the alcohol-acetone $(80: 20)$ was used, after this process to evaluate the biofilm formation was performed reading the absorbance in a reader of microplates of Elisa Easys ${ }^{\circledR}$ and measured in filter of $620 \mathrm{~nm}$.

Measurement of biofilm production by optical density. It was possible to determine the biofilm production by the following classification according to the standards obtained by optical density (OD): without biofilm production (OD sample $\leq$ OD negative control), weak biofilm production (OD negative control $<$ OD sample $\leq 2.0 D$ negative control), moderate biofilm production (OD negative control $<$ OD sample $\leq 4$.OD negative control) and strong biofilm production (OD sample $<4.0 D$ negative control). The ODm (average optical density) observed for the negative control, S. epidermidis was 0.07 , so that samples with OD values equal to or less than 0.07 are classified as without biofilm production (negative). Values of 0.07 to 0.14 are weak biofilm production, above 0.14 to 0.28 are moderate production and values above 0.28 will be classified as strong biofilm production.

Interference of the propolis extract with biofilm formation. Bacterial inocula were grown in $10 \mathrm{~mL}$ TSB with $1 \%$ glucose at $37^{\circ} \mathrm{C}$, for $24 \mathrm{~h}$. Of these, $100 \mu \mathrm{l}$ were added to the wells of the microplate, which had previously been added with $100 \mu$ l propolis extract or $100 \mu \mathrm{l}$ of culture medium in the controls.

The concentration of the extract used was equivalent to half of the $\mathrm{MBC}$ value for each isolate. Thus, after $24 \mathrm{~h}$ of incubation at $37^{\circ} \mathrm{C}$, the plates were subjected to gentian violet staining, as described in the previous topic. The efficacy of the extract in interfering with the biofilm formation was defined by the equation: mean OD of treated wells/mean OD of the control wells x 100, using data evaluation according to the methodology adapted from Nostro et al. (2007).

Interaction between propolis extract and consolidated biofilm. After the incubation period and biofilm formation, the wells were washed three times with distilled water to remove non-adhered cells and then added $200 \mu \mathrm{l}$ propolis extract $(0.5,0.25,0.125 \mathrm{MBC}),(20)$. The OD was determined immediately after addition of the extract $(0 \mathrm{~h})$ and $24 \mathrm{~h}$ after. The interference of the extract with the consolidated biofilm was defined by the equation: mean $\mathrm{OD}_{0 \mathrm{~h}} / \mathrm{m}^{\text {mean }} \mathrm{OD} \mathrm{D}_{24 \mathrm{~h}} \mathrm{x} 100$.

Statistics. The data were processed and submitted to analysis of variance, and the differences between means were determined by Tukey's test with $1 \%$ level of significance (SAS 2002). The mean $\mathrm{MBC}$ of each bacterial isolate was considered to be the response variable. The optical densities of the isolates in the presence of the propolis extracts, as well as the means related to the capacity of the extract to interfere with the consolidated biofilm were compared by the means test.

\section{RESULTS}

\section{Phytochemical analysis of propolis extract}

On the total phenolics content, the AcEOt fraction compared to the others was the one that presented the highest amount of these metabolites (Table 1), but the statistical analysis of these data was not performed. With regard to the analysis of the chromatogram obtained by HPLC and comparison with the retention times of standard flavonoids and ultraviolet spectra, it was possible to identify the substances as naringenin, kanferol and isoramnetin, the latter two being the main flavonoids of propolis.

\section{Antimicrobial activity of the propolis extracts against the isolates}

The ethanolic extract of propolis showed better efficacy (72.67\%) than the ethyl acetate extract (56.49\%) and hexane extract $(10.29 \%)$ on the Staphylococcus spp. bacteria $(\mathrm{P}<0.01)$, as shown in Table 2. However, there was no interaction $(\mathrm{P}>0.01)$ between the fractions (ethyl alcohol, ethyl acetate and hexane) as the result of MBC. In order to obtain these results, the mean $\mathrm{MBC}$ of all the extracts was considered for all the isolates. However, there were differences between the concentrations in which the best concentrations that caused the highest percentage of sensitivity were those of 6250,3125 and $1562.5 \mu \mathrm{g} / \mathrm{mL}$, these concentrations being intermediate (Table 3).

\section{Measurement of biofilm production}

The results of the biofilm production profile of the 34 isolates are shown in Figure 2, and the majority 22/34 (64.70\%) were considered weak biofilm production according to the optical density standard delimited in the methodology.

Interference of the propolis extract with biofilm formation

Only the bacterial isolates classified as moderate biofilm producers (5 isolates) were used in this assay, these isolates were characterized as coagulase-positive Staphylococci (CoPS) and all were tested for the three types of extract evaluated in the present study (Table 4). Thus, the ethanolic extract and the hexane extract were able to reduce the production profile

Table 1. Total phenolic compounds present in the propolis extract obtained from apiaries in the municipality of Casa

Nova in different chemical products, state of Bahia

\begin{tabular}{cc}
\hline Extract & Total phenolics $(\mathrm{mg} \mathrm{EAG} / \mathrm{g})^{\mathrm{a}}$ \\
\hline Ethanol & $36.21 \pm 0.08$ \\
Ethyl acetate & $63.91 \pm 0.04$ \\
Hexane & $12.63 \pm 1.08$
\end{tabular}

${ }^{\text {a }}$ Gallic acid equivalents per gram of extract.

Table 2. Efficacy profile of the diluted propolis extract in different compounds (EtOH, AcOEt and hexane) against the isolates of Staphylococcus spp. obtained from cases of caprine mastitis

\begin{tabular}{cc}
\hline Extract & Efficacy $(\%)^{*}$ \\
\hline Ethanol & $72.67^{\mathrm{a}}$ \\
Ethyl acetate & $56.49^{\mathrm{b}}$ \\
Hexane & $10.29^{\mathrm{c}}$
\end{tabular}

\footnotetext{
* The efficacy profile was obtained according to the average effect of the extract at all dilutions in the different extracts; ${ }^{a, b, c}$ mean values followed by different lowercase letters in the same column are significantly different by Tukey test at $1 \%$ probability.
} 


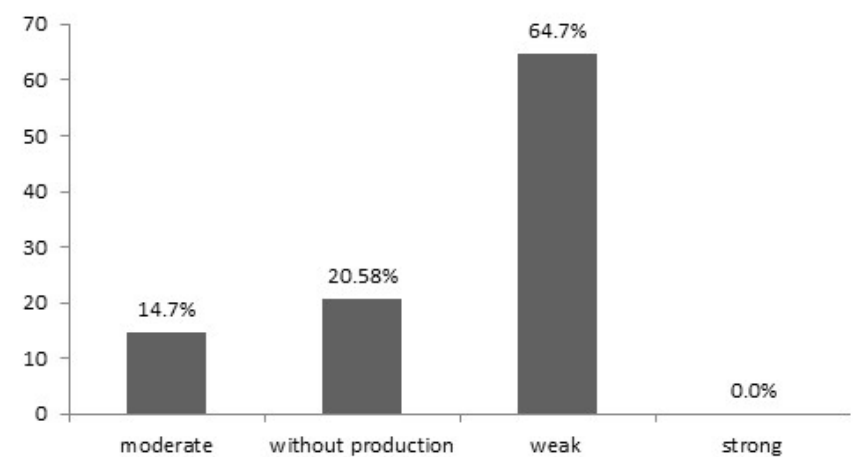

Fig.2. Measurement of biofilm production of all isolates of Staphylococcus spp.

Table 3. Sensitivity and resistance profile relationship of all isolates with CBM standards of all extracts (EtOH, AcOEt and hexane) used

\begin{tabular}{ccc}
\hline Concentrations $\mu \mathrm{g} / \mathrm{mL}$ & \% Resistant & $\%$ Sensitive \\
\hline 97.6 & $85.62^{\mathrm{a}}$ & $14.37^{\mathrm{a}}$ \\
195.3 & $71.89^{\mathrm{ab}}$ & $27.77^{\mathrm{ab}}$ \\
390.6 & $62.74^{\mathrm{ab}}$ & $37.25^{\mathrm{abc}}$ \\
781.3 & $46.73^{\mathrm{b}}$ & $53.26^{\mathrm{bc}}$ \\
1562.5 & $36.92^{\mathrm{c}}$ & $63.07^{\mathrm{c}}$ \\
3125 & $35.62^{\mathrm{c}}$ & $64.37^{\mathrm{c}}$ \\
6250 & $34.31^{\mathrm{c}}$ & $65.68^{\mathrm{c}}$ \\
12500 & $53.92^{\mathrm{b}}$ & $46.07^{\mathrm{bc}}$
\end{tabular}

a,b,c Mean values followed by different lowercase letters in the same column are significantly different by Tukey test at $1 \%$ probability.

of three and two isolates, respectively, being considered no longer a moderate producer, but rather a weak biofilm producer.

The ODm observed for the negative control was 0.066 , so that samples with DOm values equal to or less than 0.066 are classified as non-producing (negative), values between 0.066 and 0.132 are classified as weak producers, between 0.132 and 0.264 as moderate and values above 0.264 are classified as strong producers.

\section{Interaction between propolis extract and consolidated biofilm}

All extracts presented an anti-biofilm profile according to what is present in Table 5, but the ethanolic extract presented the best activity $(\mathrm{P}<0.01)$, in relation to the other extracts, since it showed a reduction of 24 hours of action.

\section{DISCUSSION}

\section{Phytochemical analysis of propolis extract}

There was a higher content of phenolic compounds in the ethyl acetate fraction (AcOEt), not discarding the other fractions that also presented significant extraction (Table 1), being the bioactive compounds identified as naringenin, kanferol and isoramnetin. Kumazawa et al. (2004) reported that when analyzing propolis from different places, materials from China and Europe contained higher levels of flavonoids
Table 4. Profile of the extracts on the biofilm in the formation of the isolates (five) considered previously moderate biofilm products

\begin{tabular}{cccc}
\hline \multirow{2}{*}{$\begin{array}{c}\text { Identification } \\
(\text { SCP })\end{array}$} & Ethanol extract & $\begin{array}{c}\text { Ethyl acetate } \\
\text { extract }\end{array}$ & Hexane extract \\
\cline { 2 - 4 } & Weak & Strong & Strong \\
$97 \mathrm{RM}$ & Weak & Strong & Weak \\
$98 \mathrm{LM}$ & Strong & Strong & Weak \\
$101 \mathrm{LM}$ & Weak & Strong & Strong \\
$102 \mathrm{RM}$ & Strong & Strong & Strong \\
$104 \mathrm{RM}$ & $489.586000^{\mathrm{ab}}$ & $613.832000^{\mathrm{a}}$ & $263.202000^{\mathrm{b}}$
\end{tabular}

$\overline{\mathrm{SCP}}=$ Staphylococcus coagulase positive, $\mathrm{RM}=$ right mammary half, $\mathrm{LM}=$ left mammary half; a,b mean values followed by different lowercase letters are significantly different by Tukey's test at $1 \%$ probability.

Table 5. Average activity profile of the extracts on the consolidated biofilm of Staphylococcus coagulase positive

\begin{tabular}{cccc}
\hline & \multicolumn{3}{c}{ Extract } \\
\cline { 2 - 4 } & Ethanol extract & $\begin{array}{c}\text { Ethyl acetate } \\
\text { extract }\end{array}$ & Hexane extract \\
\hline 0 hour & $0.624^{\mathrm{aA}}$ & $0.34^{\mathrm{bB}}$ & $0.517^{\mathrm{abA}}$ \\
24 hours & $0.423^{\mathrm{bB}}$ & $1054^{\mathrm{aA}}$ & $0.57^{\mathrm{BA}}$ \\
\hline
\end{tabular}

a,b,A,B Mean values followed by different lowercase letters, in the same row, and uppercase letters, in the same column, are significantly different by Tukey's test at $1 \%$ probability.

and phenolic acid esters. Thus, there is a medicinal potential in propolis and that this may vary according to the origin of products used to manufacture it by bees.

Several authors have reported that propolis has a range of compounds, such as flavonoids, alkaloids, terpenoids, and coumarins that reflect benefits to human and animal health, because these compounds have antimicrobial, antitumor, antioxidant activity (Cottica et al. 2011, Ortega et al. 2011, Valente et al. 2011, Chasset et al. 2016, Mouhoubi-Tafinine et al. 2016). The proportions of the various substances present in propolis depend on their place and time of collection (Wagh 2013), but not only that, the question of the locality in which the propolis was produced may be related to the presence of metabolites for therapeutic purposes.

We know that propolis is a complex mixture made by different compounds and some would be derived from plants (Wagh 2013). In general, crude propolis is composed of a mixture of several products, most of which is the resin, and the other components are waxes in addition to the essential oils (about $10 \%$ of the composition) and there is even the presence of pollen (Pietta et al. 2002, Wagh 2013). The main essential compounds responsible for biological activities are polyphenols, aromatic acids and diterpene acids (Wagh 2013) and there are not many disparities between the presence of these compounds and the different types of propolis.

\section{Sensitivity of the isolates to the propolis extract}

The ethanolic extract of propolis showed better efficacy (72.67\%) against the isolates of Staphylococcus spp., however the other extract used also obtained efficacy (Table 2). In this 
way all the products used were able to expose the bioactive compounds of propolis, highlighting the antimicrobial activity of this product. Dias et al. (2012) when studying different types of propolis in a MRSA strain, observed that all had antimicrobial activity against this strain, but the best activity was observed in the propolis of vines, which also had a greater amount of flavonoids, as well as this work an activity stands out due to the presence of this compound.

Mean MBC values of the fractions were from 12500 to $781.3 \mu \mathrm{g} / \mathrm{mL}$, with a higher sensitivity observed in intermediate values of $3125,1562.5$ and $781.3 \mu \mathrm{g} / \mathrm{mL}$, ranging from $64 \%$ to $53 \%$ values that can be justified considering that there was a better exposure of the bioactive compounds in these concentrations, favoring the bioactivity of the products. According to Aligiannis et al. (2001), values of MBC below $500 \mu \mathrm{g} / \mathrm{mL}$ are considered to be strongly inhibited, while Ríos \& Recio (2005) suggest results below $1000 \mu \mathrm{g} / \mathrm{mL}$, so the results of this work are in agreement with the results described by the authors cited, highlighting again the antimicrobial potential of propolis. We observed that in the highest concentration $(12500 \mu \mathrm{g} / \mathrm{mL})$, when we talked about microbial sensitivity, a lower sensitivity of the bacterial strains was observed (Table 3) in relation to the other dilutions, something that could be related to this would be the complexity of the extract in this dilution, because due to the great concentration and the size of its particles, the contact with the bacterial cells can be diminished, affecting the final effect of the product, which perceives an increase, as it is diluted in concentrations capable of killing the bacteria.

When it is sought to develop new drugs, the ideal would be those that have an action against a greater range of groups of microorganisms. The difference in sensitivity between Gram-positive and Gram-negative bacteria against propolis is explained by the characteristics of the cell wall composition between these groups (Najmadeen \& Kakamand 2009). However, in this work, propolis was shown to have significant activity against Gram-positive organisms, converging with studies by Dias et al. (2012) and Fernandes et al. (2015). Wagh (2013) reports that components with medicinal potential are constantly present in propolis, thus there is reinforcement that there is an antimicrobial potential in propolis due to its components.

\section{Anti-biofilm activity: consolidated and in formation}

According to the results shown in Table 3, the extract in ethyl acetate did not show any efficiency in decreasing the biofilm formation on the evaluated isolates $(\mathrm{P}>0.05)$. Also, according to Doern \& Brecher (2011), the results of in vitro tests related to antimicrobial activity do not translate as expected to that observed in vivo, herefore tests involving the use of animals become indispensable for the best evaluation of the antimicrobial potential of natural products. Bacterial resistance is associated with both the low penetration of the antimicrobial compounds in the biofilm and the phenotypically protected state induced in the bacteria that compose the biofilm, where the microbial metabolism is extremely low (Costerton et al. 1995, Altieri et al. 2013). Another factor is that bioactive products capable of affecting both biofilm formation and bacterial survival have not been completely exposed (Table 2-4), which could cause the propolis diluted in ethyl acetate to present a profile of activity near or better than that of the extract diluted in ethanol.

It was also observed that both the ethanolic extract and the hexane extract were able to interfere with the first stages of biofilm formation, with the ethanolic extract having the best effect at zero time $(\mathrm{P}<0.05)$, thus conferring a possibility of acting as a prophylactic agent at the beginning of infections. When using natural products against the production of biofilm, they are reported to act better in the initial stages of biofilm formation (Chusri et al. 2012, Salta et al. 2013). Thus, the inhibition of the biofilm in formation may be related to phenomena linked to enzymatic inhibition of protease or to the interference of bacterial quorum sensing (González-Ortiz et al. 2014). It is possible to consider that action of propolis may be related to these mechanisms, but no analysis was performed to determine this activity profile.

Thereby, biofilms are considered structures intimately associated with microbial survival in both the environment and in the host (Doern \& Brecher 2011, González-Ortiz et al. 2014). Once contained in the biofilm, bacterial cells are able to resist the host defenses and even the action of 38 antimicrobials agents, once the concentration required to cause bacterial death can be up to $1000 x$ greater (Walters et al. 2003, Fux et al. 2004, Hall-Stoodley \& Stoodley 2009).

Therefore, in the search for alternative sources to the antimicrobial treatment, much attention has been directed to substances capable of interfering with the bacterial biofilm (Issac Abraham et al. 2011, Budzyńska et al. 2011). The biofilm interferes in the mode of action of the antimicrobials, due to their low penetration, as well as to the phenotypically protected state in the bacteria that make up this structure (Jacques et al. 2010, Altieri et al. 2013). Thus, natural products such as propolis may appear as an alternative for the prevention of bacterial diseases interfering in the formation of the microbial biofilm.

\section{CONCLUSIONS}

The ethanol extract of propolis showed better efficacy against the isolates of Staphylococcus spp. and the fractions used were able to interfere both with the consolidated biolfim and during its formation.

Propolis can be considered for in vivo studies, in order to better understand its effects in uncontrolled environments.

Conflict of interest statement.- The authors have no competing interests.

\section{REFERENCES}

Acosta A.C., Silva L.B.G., Medeiros E.S., Pinheiro-Júnior J.W. \& Mota R.A. 2016. Mastites em ruminantes no Brasil. Pesq. Vet. Bras. 36(7):565-573. <http:// dx.doi.org/10.1590/S0100-736X2016000700001>

Aligiannis N., Kalpoutzakis E., Mitaku S. \& Chinou I.B. 2001. Composition and antimicrobial activity of the essential oil of two Origanum species. J. Agric. Food. Chem. 49(9):4168-4170. <http://dx.doi.org/10.1021/jf001494m> <PMid:11559104>

Altieri K.T., Sanitá P.V., Machado A.L., Giampaolo E.T., Pavarina A.C., Jorge J.H. \& Vergani C.E. 2013. Eradication of a mature methicillin-resistant Staphylococcus aureus (MRSA) biofilm from acrylic surfaces. Braz. Dent. J. 24(5):487-491. <http://dx.doi.org/10.1590/0103-6440201302289> $<$ PMid:24474290>

Bankova V.S. 2005. Recent trends and importante developments in própolis research. Evid. Based Complement Alternat Med. 2(1):29-32. <http:// dx.doi.org/10.1093/ecam/neh059> <PMid:15841275> 
Bankova V.S., De Castro S.L. \& Marcucci M.C. 2000. Propolis: recent advances in chemistry and plant origin. Apidologie 31(1):3-15. <http://dx.doi. org/10.1051/apido:2000102>

Budzyńska A., Wieckowska-Szakiel M., Sadowska B., Kalemba D. \& Rózalska B. 2011. Antibiofilm activity of selected plant essential oils and their major components. Pol. J. Microbiol. 60(1):35-41.<PMid:21630572>

Chasset T., Häbe T.T., Ristivojevic P. \& Morlock G.E. 2016. Profiling and classification of French propolis by combined multivariate data analysis of planar chromatograms and scanning direct analysis in real time mass spectra. J. Chromatogr. A 1465:197-204. <http://dx.doi.org/10.1016/j. chroma.2016.08.045><PMid:27599799>

Chusri S.N.A., Phatthalung P.N. \& Voravuthikunchai S.P. 2012. Anti-biofilm activity of Quercus infectoria G. Olivier against methicillin-resistant Staphylococcus aureus. Lett. Appl. Microbiol. 54(6):511-517.<http://dx.doi. org/10.1111/j.1472-765X.2012.03236.X ><PMid:22486208>

Clutterbuck A.L., Woods E.J., Knottenbelt D.C., Clegg P.D., Cochrane C.A. \& Percival S.L. 2007. Biofilms and their relevance to veterinary medicine. Vet. Microbiol.121(1/2):1-17.<http://dx.doi.org/10.1016/j.vetmic.2006.12.029> $<$ PMid:17276630>

Costerton J.W., Lewandowski Z., Caldwell D.E., Korber D.R. \& Lappin-Scott H.M. 1995. Microbial biofilms. Annu. Rev. Microbiol. 49(1):711-745. <http:// dx.doi.org/10.1146/annurev.mi.49.100195.003431><PMid:8561477>

Cottica S.M., Sawaya A.C.H.F., Eberlin M.N., Franco S.L., Zeoula L.M. \& Visentainer J.V. 2011. Antioxidant activity and composition of propolis obtained by different methods of extraction. J. Braz. Chem. Soc. 22(5):929-935. <http:// dx.doi.org/10.1590/S0103-50532011000500016>

Dias L.G., Pereira A.P. \& Estevinho L.M. 2012. Comparative study of different Portuguese samples of propolis: Pollinic, sensorial, physicochemical, microbiological characterization and antibacterial activity. Food Chem. Toxicol. 50(12):4246-4253.<http://dx.doi.org/10.1016/j.fct.2012.08.056> <PMid:22981908>

Doern G.V. \& Brecher S.M. 2011. The clinical predictive value (or Lack Thereof) of the results of in vitro antimicrobial susceptibility tests. J. Clin. Microbiol. 49(9):S11-S14. <http://dx.doi.org/10.1128/JCM.00580-11>

Fernandes F.H., Guterres Z.R., Violante I.M.P., Lopes T.F.S., Garcez W.S. \& Garcez F.R. 2015. Evaluation of mutagenic and antimicrobial properties of brown propolis essential oil from the Brazilian Cerrado Biome. Toxicol. Report 2:1482-1488. <http://dx.doi.org/10.1016/j.toxrep.2015.11.007> <PMid:28962491>

Fux C.A., Wilson S. \& Stoodley P. 2004. Detachment characteristics and oxacillin resistance of Staphyloccocus aureus biofilm emboli in an in vitro catheter infection model. J. Bacteriol. 186(14):486-491. <http://dx.doi. org/10.1128/JB.186.14.4486-4491.2004><PMid:15231780>

González-Ortiz G., Quarles Van Ufford H.C., Halkes S.B., Cerdà-Cuéllar M., Beukelman C.J., Pieters R.J., Liskamp R.M., Pérez J.F. \& Martín-Orue S.M. 2014. New properties of wheatt bran: anti-biofim activity and interference with bacteria quorum-seneing systems. Environ. Microbiol. 16(5):13461353. <http://dx.doi.org/10.1111/1462-2920.12441><PMid:24588934>

Hall-Stoodley L. \& Stoodley P. 2009. Evolving concepts in biofilm formation. Cell Microbiol. 11(7):1034-1043. <http://dx.doi. org/10.1111/j.1462-5822.2009.01323.X> <PMid:19374653>

Issac Abraham S.V., Palani A., Ramaswamy B.R., Shunmugiah K.P. \& Arumugam V.R. 2011. Antiquorum sensing and antibiofilm potential of Capparis spinosa. Arch. Med. Res. 42(8):658-668. <http://dx.doi.org/10.1016/j. arcmed.2011.12.002><PMid:22222491>

Jacques M., Aragon V. \& Tremblay Y.D. 2010. Biofilm formation in bacterial pathogens of veterinary importance. Anim. Health Res. Rev. 11(2):97-121. <http://dx.doi.org/10.1017/S1466252310000149><PMid:20969814>

Kumazawa S., Hamasaka T. \& Nakayama T. 2004. Antioxidant activity of propolis of various geographic origins. Food Chem. 84(3):329-339.<http:// dx.doi.org/10.1016/S0308-8146(03)00216-4>
Leitner G., Merin U., Krifucks O., Blum S., Rivas A.L. \& Silanikove L. 2012. Effects of intra-mammary bacterial infection with coagulase negative staphylococci and stage of lactation on shedding of epithelial cells and infiltration of leukocytes into milk: comparison among cows, goats and sheep. Vet. Immunol. Immunopathol. 147(3/4):202-210. <http://dx.doi. org/10.1016/j.vetimm.2012.04.019><PMid:22584045>

López D., Vlamakis H. \& Kolter R. 2010. Biofilms. Cold Spring Harb. Perspect. Biol. 2(7):1-11. <http://dx.doi.org/10.1101/cshperspect.a000398> $<$ PMid:20519345>

Marcucci M.C. 1995. Propolis: chemical composition, biological properties and therapeutic activity. Apidologie 26(2):83-99. <http://dx.doi.org/10.1051/ apido:19950202>

Mello B.C.B.S., Petrus J.C.C. \& Hubinger M.D. 2010. Performance of nanofiltration concentration process in propolis extracts. Ciênc. Tecnol. Aliment. 30(1):166172. <http://dx.doi.org/10.1590/S0101-20612010000100025>

Merino N., Toledo-Arana A., Vergara-Irigaray M., Valle J., Solano C., Calvo E., Lopez J.A., Foster T.J., Penadés J.R. \& Lasa I. 2009. Protein A- mediated multicellular behavior in Staphylaccocus aureus. J. Bacteriol. 191(3):832843. <http://dx.doi.org/10.1128/JB.01222-08> <PMid:19047354>

Miyataka H., Nishiki M., Matsumoto H., Fujimoto T., Matsuka M., Isobe A. \& Satoh T. 1998. Evaluation of propolis (II): effects of Brazilian and Chinese propolis on histamine release from rat peritoneal mast cells induced by compound 48/80 and concanavalin A. Biol. Pharm. Bull. 21(7):723-729. <http://dx.doi.org/10.1248/bpb.21.723><PMid:9703257>

Mouhoubi-Tafinine Z., Ouchemoukh S. \& Tamendjari A. 2016. Antioxydant activity of some algerian honey and própolis. Industr. Crops Prod. 88:8590. <http://dx.doi.org/10.1016/j.indcrop.2016.02.033>

Najmadeen H.H. \& Kakamand F.A.K. 2009. Antimicrobial activity of propolis collected in different regions of Sulaimani province-Kurdistan region, Iraq. J. Duhok Univ. 12(1):233-239.

Nostro A., Sudano Roccaro A., Bisignano G., Marino A., Cannatelli M.A., Pizzimenti F.C., Cioni P.L., Procopio F. \& Blanco A.R. 2007. Effects of oregano, carvacrol and thymol on Staphylococcus aureus and Staphylococcus epidermidis biofilms. J. Med. Microbiol. 56(4):519-523. <http://dx.doi.org/10.1099/ jmm.0.46804-0 > <PMid:17374894>

Ortega N.S., Benitez-Campo N. \& Cabezas-Fajardo F.A. 2011. Actividad antibacterial y composición cualitativa de propóleos provenientes de dos zonas climáticas del Departamento del Cauca. Revta. Bio. Agro. 9(1):8-16.

Peixoto R.M., Araújo R.M.P., Peixoto L.J.S., Bonfim S.A.G., Silva T.M.G., Silva T.M.S., Almeida J.R.G.S., Mota R.A. \& Costa M.M. 2015. Treatment of goat mastitis experimentally induced by Staphylococcus aureus a formulation containing Hymenaea martiana extract. Small Rumin. Res. 130:229-235. <http://dx.doi.org/10.1016/j.smallrumres.2015.07.009>

Pereira I.M., Andrade L.A., Barbosa M.R.V. \& Sampaio E.V.S.B. 2002. Composição florística e análise fitossociológica do componente arbustivo-arbóreo de um remanescente florestal no agreste paraibano. Acta Bot. Bras. 16(3):357369. <http://dx.doi.org/10.1590/S0102-33062002000300009>

Pietta P.G., Gardana C. \& Pietta A.M. 2002. Analytical methods for quality control of propolis. Fitoterapia 73(Suppl.1):S7-S20.<http://dx.doi.org/10.1016/ S0367-326X(02)00186-7><PMid:12495705>

Popova M., Trusheva B., Antonova D., Cutajar S., Mifsud D., Farrugia C., Tsvetkova I., Najdenski H. \& Bankova V.2011. The specific chemical profile of Mediterranean propolis from Malta. Food Chem. 126(3):1431-1435. <http://dx.doi.org/10.1016/j.foodchem.2010.11.130>

Ríos J.L. \& Recio M.C. 2005. Medicinal plants and antimicrobial activity. J Ethnopharmacol. 100(1/2):80-84. <http://dx.doi.org/10.1016/j. jep.2005.04.025><PMid:15964727>

Sá M.C.A., Peixoto R.M., Krewer C.C., Almeida J.R.G.S., Vargas A.C. \& Costa M.M. 2011. Antimicrobial activity of caatinga biome ethanolic plant extracts against gram negative and positive bactéria. Revta Bras. Ciênc. Vet. 18(2/3):62-66. 
Salta M., Wharton J.A., Dennington S.P., Stoodley P. \& Stokes K.R. 2013. Antibiofilm performance of three natural products against initial bacterial attachment. Int. J. Mol.Sci. 14(11):21757-21780. <http://dx.doi.org/10.3390/ ijms141121757> <PMid:24192819>

Sampimon O., van den Borne B.H.P., Santman-Berends I., Barkema H.W. \& Lam T. 2010. Effect of coagulase-negative staphylococci on somatic cell count in Dutch dairy herds. J. Dairy Res. 77(3):318-324. <http://dx.doi. org/10.1017/S0022029910000191><PMid:20450528>

SAS 2002. SAS/STAT 9.1 User's guide. Statistical Analysis System. 5136p.

Sforcin J.M. \& Bankova V. 2011. Propolis: is there a potential for the development of new drugs? J. Ethnopharmacol. 133(23):253-260. <http://dx.doi. org/10.1016/j.jep.2010.10.032><PMid:20970490>

Silva J.C., Rodrigues S., Feás X. \& Estevinho L.M. 2012. Antimicrobial activity, phenolic profile and role in the inflammation of propolis. Food Chem. Toxicol. 50(5):1790-1795. <http://dx.doi.org/10.1016/j.fct.2012.02.097> <PMid:22425940>
Valente M.J., Baltazar A.F., Henrique R., Estevinho L. \& Carvalho M. 2011. Biological activities of Portuguese propolis: protection against free radical-induced erythrocyte damage and inhibition of human renal cancer cell growth in vitro. Food Chem. Toxicol. 49(1):86-92. <http://dx.doi. org/10.1016/j.fct.2010.10.001><PMid:20934479>

Vargas A.C., Loguercio A.P., Witt N.M., Costa M.M., Silva M.S. \& Viana L.R. 2004. Atividade antimicrobiana in vitro de extrato alcóolico de própolis. Ciência Rural 36(1):159-163. <http://dx.doi.org/10.1590/S0103$84782004000100024>$

Wagh V.D. 2013. Propolis: a wonder bees product and its pharmacological potentials. Adv. Pharmacol. Sci. 2013:11. <http://dx.doi.org/10.1155/2013/308249> <PMid:24382957>

Walters 3rd M.C., Roe F., Bugnicourt A., Franklin M.J. \& Stewart P.S. 2003. Contributions of antibiotic penetration, oxygen limitation, and low metabolic activity to tolerance of Pseudomonas aeruginosa biofilms to ciprofloxacin and tobramycin. Antimicrob. Agents Chemother. 47(1):317-323. <http:// dx.doi.org/10.1128/AAC.47.1.317-323.2003> <PMid:12499208> 